\title{
THE VALIDATION OF THE SERBIAN VERSION OF THE GENERAL ANXIETY DISORDER SCALE (GAD7): A PILOT STUDY
}

\section{Nikola Rokvić}

Faculty of Law and Business Studies

"Dr Lazar Vrkatić",

Union University,

Novi Sad, Serbia

UDK: 616.89-008-02-08

doi: $10.5937 /$ engrami1902068R

\section{Summary}

Introduction. Among the four most common anxiety disorders, not counting simple phobias, are the panic disorder, social anxiety disorder, posttraumatic stress disorder and general anxiety disorder (GAD). One of the main distinctions of the generalized anxiety disorder, and indeed its core defining feature, is the chronic and persistent sense of worry. The GAD7 screener has been specifically designed to target and measure this disorder.

Objective. It is the aim of this study to perform a pilot validation of the Serbian translation of the GAD7 questionnaire.

Method. We performed two separate sampling surveys for our study, the first sample in an online survey of the general population $(\mathrm{N}=344)$, and a paper and pencil survey of the student population $(\mathrm{N}=230)$.

Results. We performed exploratory (Keiser-Meyer-Olkin $=0.905$; 
$\chi 2=1093.435 \quad(\mathrm{DF}=21 ; \mathrm{p}<0.001))$ and confirmatory (AGFI $=0.801$; $\mathrm{CFI}=0.937$; RMSEA $=0.151 ; \quad E C V I=0.503$ ) factor analysis that have proven favorable to the proposed model. The mean GAD7 score was $6.91(\mathrm{SD}=5.21)$. In $\mathrm{S} 2$ this score correlated positively with Neuroticism ( $r=0.64)$, Negative affect $(r=0.71)$, Stress $(\mathrm{r}=0.78)$, Depression $(\mathrm{r}=0.58)$ and Anxiety $(\mathrm{r}=0.69)$. Female participants register higher scores than males as in all similar studies and this also goes in favor of the scales validity.

Conclusion. In our pilot study we have shown that the GAD-7 questionnaire is a viable measure of the generalized anxiety disorder but further research on clinical and general populations are needed to strengthen this claim.

\section{Key words:}

Factor Analysis, Stress Disorders, Neuroticism, Surveys and Questionnaires

\section{INTRODUCTION}

Among the four most common anxiety disorders (not counting simple phobias) are the panic disorder, social anxiety disorder, posttraumatic stress disorder (PTSD) and general anxiety disorder $(\mathrm{GAD})^{[1]}$. One of the main distinctions of the generalized anxiety disorder, and indeed its core defining feature, is the chronic and persistent sense of worry ${ }^{[2]}$. This worry is distinguished by the fact that it can be multifocal concentrating on issues like finances, health, family and the future. Except for worry there are other accompanying symptoms such as hyperarousal and counterproductive and debilitating fear ${ }^{[3]}$. Suffering from one form of anxiety disorders represents a risk of developing other anxiety and mood disorders and substance abuse. The great number of clinical comorbidities that are developed alongside anxiety disorders makes them especially hard to treat in clinical cases ${ }^{[4]}$. The far reaching influence of the GAD can also be seen in attention bias where those suffering from GAD are more sensitive to threat components of elicited stimuli ${ }^{[5]}$ On the other hand there is no conclusively detected difference between those persons suffering from GAD and other anxiety disorder.

The estimated general anxiety disorder prevalence in the US general population is $3.1 \%{ }^{[2]}$. In the $\mathrm{EU}$ there are more than 60 million people suffering from anxiety disorders at any given time 
making it the most prevalent psychiatric disorders in the $\mathrm{EU}^{[6]}$. If left untreated, anxiety can be asociated with significant personal and social cost associated with frequenly seeking medical attention in primary and acute care facilities, decreased work productivity, unempleument and strained social relationships ${ }^{[4]}$. Concordantly in primary care between $17 \%$ do $22.1 \%$ of patients suffer from at least one anxiety disorder, and between $5.9 \%$ and $9.4 \%$ of them suffer from general anxiety, a close second to PTSD ${ }^{[1]}$. This represents a burden on the health care system where it is estimated that in 2004 alone anxiety disorders on their own cost 41 billion Euros in the $\mathrm{EU}^{[7]}$. $\mathrm{Pa}$ tients suffering from anxiety are prone to substance abuse, most commonly to all forms of alcohol abuse ${ }^{[8]}$.

With regards to gender the prevalence of GAD is at least twice as high in women than in men ${ }^{[9]}$. Anxiety disorders can last for decades, and they begin in in childhood and adolescence mostly while reaching their peak in middle age to again decrease in severity as the person gets older. There are speculations that there are cultural differences in GAD prevalence but the available studies are too heterogeneous to scientifically back such a claim. GAD levels also decrease with higher levels of education, in persons living with a partner, higher levels of income and rural areas ${ }^{[10]}$.

The General Anxiety Disorders - 7 item (GAD-7) scale was originally de- veloped on the sample of primary care patients for clinical diagnostic use. Out of the original 13 items that covered all of the Diagnostic and Statistical Manual of Mental Disorders, Fourth Edition (DSM-IV) symptom criteria for GAD and items created on the basis of review of existing anxiety scales ${ }^{[11]}$. The screener was later standardized on the general population ${ }^{[10]}$, and has since been translated and standardized in many languages and cultures such as Spanish ${ }^{[12]}$, Portugese $^{[13]}$ and others. Because of its shortner and constant crosscultural reliability this scale is considered optimal for degermining the existance and the severity of GAD.

\section{OBJECTIVE}

The aim of our study was to determine the reliability and the factorial structure of the Serbian translation of the GAD-7 scale and its interaction with related constructs.

\section{METHOD}

The first sample (S1) consisted out of 344 participants, 256 (74.4\%) of them declared themselves as female. The mean age of the sample was 27.8 years $(\mathrm{SD}=8.42)$ ranging from 18 to 61 . Regarding education level, $44.2 \%$ of participants were students, $23.3 \%$ finished graduate level education, $10.2 \%$ finished highs school education, $18.6 \%$ finished 
aster level education and 3.8\% hold a $\mathrm{PhD}$ degree. As to the employment status $37.5 \%$ are unemployed students, $17.7 \%$ are unemployed, $13.7 \%$ are precariously employed and 31.1 are permanently employed. $10.5 \%$ of the sample reported to be suffering from some sort of chronic disorder. The sample was collected using social networks. A survey was created using Google forms and it was circulated freely, open for all users, in other words members of the general population that uses social networks, to participate in. The afore mentioned survey consisted out of a battery of tests besides GAD-7. These tests include included the DASS21 questionnaire, Neuroticism subscale from The Big Five Inventory, the negative affect subscale of the PANAS questionnaire along with the GAD-7 scale. This community sample was intended for exploratory factor analysis and determining the relationship of anxiety measured by the GAD7 scale with other measured constructs.

The second sample (S2) consisted out of 230 participants, out of them 184 (80\%) declared themselves as female, with an average age of 20.97 ( $S D=20.97$; $\min =18 ; \max =27$ ), consisted entirely of students. This sample was gathered to conduct confirmatory factor analysis of the GAD-7 questionnaire. It was collected using the pencil and paper method on university students.

In order to better explore the average and age group related levels of general anxiety, as determined by the GAD-7 questionnaire, we have combined both samples into sample 3 (S3), consisting out of a total of 574 participants, 440 of them female (76.7\%), with an average age of 25.06 ( $\mathrm{SD}=7.497 ; \min =18 ; \max =61$ ).

Next we will describe the instruments used in the S1 battery of tests. Each of these instruments has been carefully chosen because they measure construct related to general anxiety, and thus functioning as another tool for the validation of GAD-7 by examining their interactions with it. Also it is important to mention that the links between the chosen constructs are well documented in literature as will be discussed later.

\section{GAD-7}

The GAD-7 questionnaire is designed to measure levels of generalized stress. It consists out of seven items that are answered on a seven point Liquert scale. Its internal consistency is good, with a values in S1, S2 and S3, of 0.88, 0.93 and 0.9 respectively. The scale was translated in the Serbian language by bilingual experts in the field of medicine and psychology.

\section{DASS-21}

The Depression, Anxiety and Stress Scale 21 consist out of 21 items sorted into three subscales, depression, stress and anxiety, with 7 items each. In our sample these subscales show excellent internal consistency, with a value of $0.89,0.88$ and 0.88 , respectively. This questionnaire was 
validated in the Serbian language and has proven positive psychometric characteristics $^{[14]}$. The items are answered on a 4 point scale.

\section{BFI}

We used the Neuroticism subscale from The Big Five Inventory. The original instrument contained 44 items and has repeatedly shown good metric characteristics. The neuroticism subscale consists out of 8 items that measure responses on a 5 point Liquert scale. The internal consistency of this subscale in our sample was somewhat lacking with Crombach alpha values of 0.69 .

\section{PANAS}

In our battery of tests we used the Negative emotion subscale of the Serbian translation of the Positive and Negative Affect Schedule (PANAS). This scale has been translated and validated in the Serbian language ${ }^{[15]}$. The subscale consists out of 10 items and it has a value of 0.88 .

Out of statistical methods we used descriptive statistics, exploratory and confirmatory factor analysis, one way ANOVA and Spearman's correlation index.

\section{RESULTS}

Exploratory factor analysis was performed on S1 sample. Keiser-Meyer-Olkin coefficient was .905 with a $\chi 2$ value of $1093.435(\mathrm{DF}=21 ; \mathrm{p}<.001)$. There is only one principal component that explains $58.72 \%$ of the variance. Individual component loadings are presented in table 1. Confirmatory factor analysis was performed on the S2 sample with a calculated $\chi^{2}$ value of $87.12(\mathrm{DF}=14 ; \mathrm{p}<.001)$. Model fit parameters are the following AGFI $=0.801$; CFI $=0.937$; RMSEA $=0.151$; $\mathrm{ECVI}=0.503$. Individual squared factor loadings for every item in confirmatory factor analysis are available in Graph 1. Correlations between anxiety as measured by the GAD-7 screener and other measured constructs in S2 are presented in Table 2.

The mean values of the GAD-7 screener was $6.91 \quad(\mathrm{SD}=5.21 ; \min =0$; $\max =21$ ). There is a statistically significant difference of general anxiety levels between genders $(\mathrm{p}<0.001)$ with female scores (7.3; $\mathrm{SD}=5.38)$ registering higher than male scores (5.64; $\mathrm{SD}=4.38)$. There is no significant correlation between age and generalized anxiety levels. Generalized anxiety levels per age group have been represented in Table 3. Also a breakdown of anxiety levels per employment status and education level can also be found in Table 3 .

We have performed ANOVA analysis in order to determine is there any statistically significant difference between general anxiety levels between age groups, different educational levels and employment statuses. For age ANOVA was not significant $(\mathrm{F}(\mathrm{df})=1.6(573)$; $\mathrm{p}=0.174)$. With regards to the educa- 
tional status ANOVA was significant $(F(d f)=3.96(343) ; p=0.004)$. Those participants with master level education have significantly lower levels of generalized anxiety than students $(\mathrm{p}=0.04)$ and those participants with high school level education $(\mathrm{p}=0.005)$. Regarding employment status $(\mathrm{F}(\mathrm{DF})=3.43$ (343); $\mathrm{p}=0.017$ ) differences are significant only between students and permanently employed $(\mathrm{p}=0.013)$.

\section{DISCUSSION}

Exploratory and confirmatory factor analysis have confirmed the exceptional psychometric properties of the Generalized Anxiety Disorder- 7 item scale, showing that it is viable for use with regard to this criteria. Gender differences have been reported in the original study ${ }^{[11]}$ and later in the validation and standardization of the scale in the general population ${ }^{[3,10]}$ and they significant. Replicating this score in our study goes a long way into establishing the validity of the Serbian translation of GAD-7.

Levels of anxiety measured are a bit more difficult to interpret. Generally the value of 6.91 is within the span of mild anxiety ${ }^{[1]}$ but these values are relevant for clinical populations. The highest levels were detected in students, and this population approached clinical values where it is suggested that $8 \%$ of students, given their average GAD-7 score of 8.01) might be suffering from Generalized
Anxiety Disorder ${ }^{[16]}$. On the other hand when considering the results of Lowe et al. (2008) that have measured 3.2 for female and 2.66 for male participants in the general population the results we have accumulated are alarming. The large population of students in our sample, the group reporting highest anxiety levels is probably significantly driving up the GAD-7 score; therefore a broader survey of the general population is necessary to get the complete picture of the population's anxiety levels.

With regards to age anxiety levels are supposed to rise as the participants get older ${ }^{[10]}$. Anxiety has been shown to rise with the onset and intensification of chronic diseases ${ }^{[3]}$ and with mental health quality of life in the elderly ${ }^{[17]}$. This however does not happen to be the case in our study. It is true that our sample of the elderly is extremely small therefore we cannot get a clear enough picture, but again the sample of young people dominated by students has the highest levels of anxiety measured.

With regard to education levels ${ }^{[10]}$ do register a peak in GAD-7 scores in those with high-school level education, but their highest registered levels are in those with grade school education and our survey did not cover that group. This does not correspond with our findings since those with graduate level education register the highest scores with a sharp decline when those with master level education are concerned. This can perhaps be ex- 
plained that some of those with graduate level education are still in the education system attaining their masters therefore making them in a sense students, the most anxious group in our survey, but still their levels are greater even then those of undergraduate students. Perhaps the fact that they soon to join the labor market is causing these anxiety levels but this is pure conjecture at this point.

With regards to employment those with permanent employment have the lowest levels of anxiety, while those unemployed have the highest general anxiety levels. Again in our study student levels are higher than those that are unemployed following the established trend in our study. The stability in life that is provided by permanent employment is definitely a significant factor in reducing general anxiety, while those precariously employed are under more pressure and of course those that are unemployed therefore we find these findings expected.

The connection between anxiety and trait neuroticism is well established ${ }^{[18]}$, as is the one with negative affect ${ }^{[15]}$. This has been amply proven in our study with very strong correlation indices between GAD7 scores and these constructs. Indeed this goes greatly in favor of the scales validity in the Serbian language. Correlation between GAD-7 and DASS21 give us an interesting insight. GAD-7 scores correlate more strongly with stress than with anxiety subscales of the DASS21 questionnaire. This positioning gives us a clearer picture of the positioning of the general anxiety disorder on the pallet of psychological distress factor in our cultural context. General anxiety disorder with is specificity, the constant and oppressive fear of worry, is closer to the feeling of stress than it is to overall anxiety as measure by DASS21. This finding can perhaps explain the greater levels of general anxiety measured in the student population.

However we cannot conclude the discussion of this study without addressing some of its limitations. Most of the sample is consists of the students there fore we do not have the most accurate overview of the general population. Larger scale studies are needed in order to more precisely measure the baseline values for particular demographics, especially age related. A clinical sample has not been included in this study but it is necessary to perform such a study to further validate the scale and create appropriate baseline values for clinical entities in our cultural context.

\section{CONCLUSION}

In conclusion given our findings we conclude that the Serbian translation of the GAD-7 is a valid and viable instrument for measuring the levels of generalized anxiety disorder. This is proven by its favorable psychometric characteristics and its divergent validity with regards to gender and other measured constructs. 


\section{VALIDACIJA SRPSKE \\ VERZIJE SKALE \\ GENERALIZOVANOG \\ ANKSIOZNOG POREMEĆAJA \\ (GAD7): PILOT STUDIJA}

\section{Nikola Rokvić}

Fakultet za pravne i poslovne studije

„Dr Lazar Vrkatic“",

Univerzitet Union,

Novi Sad, Srbija

UDK: 616.89-008-02-08

doi: $10.5937 /$ engrami1902068R

\section{Kratak sadržaj}

Uvod. Među četiri najčešća poremećaja anksioznosti, ne računajući jednostavne fobije, spadaju panični poremećaj, socijalni anksiozni poremećaj, posttraumatski stresni poremećaj i genralizovani anksiozni poremećaj (GAP). Jedna od glavnih specifičnosti generalizovanog anksioznog poremećaja i njegova osnovna karakteristika je hronično i postojano osećanje zabrinutosti. Skrining upitnik GAD-7 specijalno je dizajniran da prepozna i meri ovaj poremećaj.

Cilj. Cilj ovog istraživanja je pilot validacija srpskog prevoda GAD-7 upitnika.

Metod. U istraživanju smo sproveli ispitivanje na dva odvojena uzorka, prvo na uzorku opšte populacije $(\mathrm{N}=344)$ online upitnikom, a zatim na uzorku studentske populacije $(\mathrm{N}=230)$ pomoću papirne forme upitnika.

Rezultati. Obavili smo eksplorativnu (Keizer-Meier-Olkin $=0.905 ; \chi^{2}=$ $1093.435(\mathrm{df}=21 ; \mathrm{p}<0.001))$ i konfirma- 
tornu (AGFI $=0.801$; CFI $=0.937$; RM$\mathrm{SEA}=0.151$; ECVI $=0.503)$ faktorsku analizu koje su se pokazale adekvatnim za predloženi model. Srednji rezultat GAD-7 bio je $6.91(\mathrm{SD}=5.21)$. U S2 ovaj rezultat pozitivno korelira sa neurotizmom $(\mathrm{r}=0.64)$, negativnim afektom $(r=0.71)$, stresom $(r=0.78)$, depresijom $(r=0.58)$ i anksioznošću $(r=0.69)$. Žene beleže više skorove od muškaraca kao u svim sličnim studijama i to takođe ide u prilog validnosti skale.
Zaključak. U našoj pilot studiji pokazali smo da je GAD-7 upitnik upotrebljiv instrument procene generalizovanog anksioznog poremećaja, ali potrebna su dalja istraživanja kliničke i opšte populacije da bi se ojačala ova tvrdnja.

\section{Ključne reči:}

faktorska analiza, stres (poremećaj), neuroticizam, ankete i upitnici

\section{APPENDIX}

\section{Table 1 / Tabela 1:}

Exploratory factor analysis of the GAD-7 screener on the S1 sample $(\mathrm{N}=344)$ / Eksplorativna faktorska analiza GAD-7 skrining upitnika na S1 uzorku (N=344)

\begin{tabular}{l|c}
\multicolumn{1}{c|}{ Item } & Loading \\
\hline 1. Osećaj nervoze, anksioznosti ili da sam na ivici & 0.749 \\
\hline 2. Nisam mogao/la da prestanem da brinem ili da kontrolišem brigu. & 0.868 \\
\hline 3. Brinem preterano o različitim stvarima. & 0.785 \\
\hline 4. Imao/la sam poteškoće da se smirim. & 0.792 \\
\hline 5. Bio/la sam toliko nervozan/a da mi je bilo teško da sedim mirno. & 0.772 \\
\hline 6. Bio me je lako razdražiti ili iznervirati. & 0.701 \\
\hline 7. Osećao/la sam strah kao da bi se nešto jako loše moglo desiti. & 0.681 \\
\hline \hline
\end{tabular}

Figure 1 / Slika 1:

Diagram of confirmatory factor analysis final structural model

/ Dijagram konfirmatorne faktorske analize konačnog strukturalnog modela

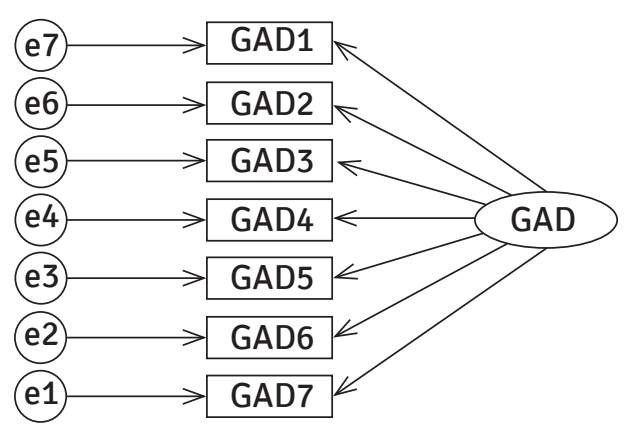


Table 2 / Tabela 2:

Correlations between anxiety as measured by GAD7 questionnaire and other measured constructs in S2 test battery / Korelacije između anksioznosti merene GAD-7 upitnikom i ostalih merenih konstrukata u S2 bateriji testova

\begin{tabular}{l|c}
\multicolumn{1}{c|}{ Measured constructs } & GAD-7 ( $r$ value) \\
\hline Neuroticism (BFI) & $0.642^{* *}$ \\
\hline Negative affect (PANAS) & $0.713^{* *}$ \\
\hline Stress (DASS-21) & $0.784^{* *}$ \\
\hline Depression (DASS-21) & $0.576^{* *}$ \\
\hline Anxiety (DASS-21) & $0.686^{* *}$ \\
\hline \hline
\end{tabular}

** Correlation is significant at the 0.01 level

Table 3 / Tabela 3:

GAD-7 levels per age group, education level and employment status / Nivoi GAD-7 u odnosu na starosnu grupu, nivo obrazovanja i zaposlenje

\begin{tabular}{l|c|c}
\multicolumn{1}{c|}{ Age (years) (N=574) } & $\mathbf{N}(\%)$ & GAD-7 (mean) \\
\hline $18-29$ & $454(79.1 \%)$ & 7.19 \\
\hline $30-39$ & $93(16.2 \%)$ & 5.83 \\
\hline $40-49$ & $14(2.4 \%)$ & 5.50 \\
\hline $50-59$ & $11(1.9 \%)$ & 6.64 \\
\hline $60-69$ & $2(0.3 \%)$ & 7.5 \\
\hline Education level (N=344) & $\mathbf{N}(\%)$ & $\mathbf{G A D}-7$ (mean) \\
\hline High school level & $35(10.2 \%)$ & 7.03 \\
\hline Student & $152(44.2 \%)$ & 8.38 \\
\hline Graduate level education & $80(23.2 \%)$ & 5.41 \\
\hline Master level education & $64(18.6 \%)$ & 4.92 \\
\hline PhD level education & $13(3.8 \%)$ & $\mathbf{6 A D}-7$ (mean) \\
\hline Employment status (N=344) & $\mathbf{N}(\%)$ & 7.2 \\
\hline Student & $129(37 \%)$ & 6.42 \\
\hline Unemployed & $61(17.7 \%)$ & 6.1 \\
\hline Precariously employed & $47(13.7 \%)$ & \\
\hline Permanently employed & $107(31.1 \%)$ & \\
\hline \hline
\end{tabular}




\section{LITERATURE / LITERATURA}

1. Kroenke K, Spitzer RL, Willi2 ams JB, Monahan, PO, Lowe, B. Anxiety Disorders in Primary Care: Prevalence, Impairment, Comorbidity and Detection. Ann Intern Med 2007; 147:317-25.

2. Stein MB, Jitender S. Generalized Anxiety Disorder. N Engl J Med 2015; 373:2059-68.

3. Remes 0 , Bryne $C$, van der Linde R, Lafortune L. A systemic review of reviews on the prevalence of anxiety dissorders in adult populations. Brain Behav 2016; 6(7): e00497.

4. Simpson HB. Neria Y, Lewis-Fernandez $R$, Schneirer, F. Anxiety disorders - theory, research and clinical perspectives. Cambridge: Cambridge University Press 2010.

5. Goodwin H, Yiend J, Hirsch C. Generalized Anxiety Disorder, worry and attention to threat: A systemic review. Clin Psychol Rev 2017; 54:10722.

6. Wittchen HU, Jacobi F, Rehm J, Gustavsson A. The size of the burden of the mental dissorders and other dissorders of the brain in Europe. Eur Neuropsychopharmaco 2011; 31(9): 655-79.

7. Andlin-Sobocki P, Wittchen HU. Cost of anxiety disorders in Europe. Eur J Neurol 2005; 12(1): 39-44.

8. Lai HM, Cleary M, Sitharthan T, Hunt GE. Prevalence of comorbid substance use, anxiety and mood dissorders in epidemiological survays, 1990-2014: A systemic review and meta-analysis. Drug Alcohol Depend 2015; 154:1-13.

9. Bandelow B, Michaelis S.
Epidemiology of anxiety in the 21st century. Dialogues Clin Neurosci 2015; 17(3):327-35.

10. Lowe B, Decker O, Muller S, Brahler E, Schellberg D, Herzog W, et al. Validation and Standardization of the General Anxiety Disorder Screener (GAD-7) in the General Population. Med Care 2008; 46(3):266-74.

11.Spitzer RL, Kroenke K, Williams JB, Lowe B. A brief Measure for Assessing the Generalized Anxiety Disorder: The GAD-7. Arch Intern Med 2006;166(10):1092-97.

12. Garcia-Campayo J, Yamorano E, Ruiz MA, Pardo A, Perey-Paramo M, LopezGomez V, et al. Cultural adaptation into Spanish of the generalized anxiety disorder-7 (GAD-7) scale as a screening tool. Health Qual Life Outcomes 2010; 8(8): https://doi. org/10.1186/1477-7525-8-8

13. Sousa TV, Viverios V, Chai MV, Vicente FL, Jesus G, Carnot JM, et al. Reliability and validation of the Portugese version of the Generalizad Anxiety Disorder (GAD-7) scale. Health Qual Life Outcomes 2015; 13: https:// doi.org/10.1186/s12955-015-0244-2

14. Jovanovic V, Gavrilov-Jerkovic V, Zuljevic D, Brdaric D. Psychometric evaluation of the DEpression Anxiety Stress Scales-21 (DASS-21) in a Serbian student population. Psihologija 2014; 47(1): 93-112.

15. Mihic L, Novovic Z, Colovic P, Smederevac $S$. Serbian Adaptation of the Positive and Negative Affect Schedule (PANAS): Its Facets and Second-Order Structure. Psihologija 2014; 47(4): 393-414.

16. Swinson RP. The GAD7 scale was 
accurate for diagnosing general

anxiety disorder. BMJ Evid Based Med

2006; 184.

17. Wild B, Eckl A, Herzog W, Niehoff D, Lechner S, Maatouk I, et al. Assessing General Anxiety Disorder in Elderly people Using the GAD-7 and GAD-2

Scales: Results of a Validation Study. Am J Geriatr Psychiatry 2014; 22(10): 1029-38.

18. Karsten J, Penninx, BW, Riese $H$, Ormel J, Noel WA, Hartman CA. The state effect of depressive and anxiety dissorders on the big five personality traits. J Psychiatr Res 2012; 46(5):, 644-50.

Nikola Rokvić

Novosadskog sajma 29,

21000 Novi Sad, Srbija

nikola.rokvic@flv.edu.rs 